\title{
Analysis of Limb Posture in Ratitae Bipedal Locomotion
}

正 原 敬 （同志社大）正横川 隆一 （同志社大） ○学 河原 史朗 （同志社大）

Kei HARA, Doshisha University, Tatara Totani 1-3, Kyoutanabeshi, Kyoto

Ryuichi YOKOGAWA, Doshisha University

Fumiaki KAWAHARA, Doshisha University

\begin{abstract}
In this paper, the limb posture during the bipedal locomotion of ratitaes were examined by creating simple link models based on videotapes of each bird during locomotion. The model was balanced by comparing them with photos of skeletons and using known bone length ratios. Two methods were used to determine the location of the center of mass (CM), in which both methods confirmed the same location. From these models, the exhibition of long double-leg support phases and minute $\mathrm{CM}$ vertical motion became apparent. The kinetics of locomotion shows similarities with models using the Linear Inverse Pendulum Method. Analysis of limb posture by the introduction of manipulability ellipsoids suggests that limb posture of both support and swing legs are advantageous for bipedal locomotion.
\end{abstract}

Key Words : Bird, Bipedal Locomotion, Inverse Pendulum, Manipulator

\section{1. 啨言}

現生動物の中で 2 足歩行を行うものとして，人間の他に 鳥類が上げられる。特に鳥は，人間と比べて脳容量が小さ いにもかかわらず，人間のように転倒の衝撃を和らげてく れるような腕を必要としない, 安定した歩行運動を行うこ とで知られている．今まで，生物学的に鳥の脚の形態を調

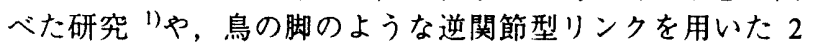
足歩行ロボットの研究 ${ }^{2)}$ はなされてきたが, 実際の鳥の歩 行安定性を定量的に評価した研究は行われていない.

そこで本研究では, 鳥の歩行の 2 次元運動学評価を行い, その歩行特性を倒立振子理論と比較し, 歩行における鳥の 脚の姿勢を評価することを目的とする。

\section{2. 县の步行モデルの作成}

ビデオカメラで収めた各鳥の歩行運動をもとにモデル図 を作成した，画像から読み取れない関節位置は，鳥の骨格 画像と，Gatesy" ${ }^{1)}$ が集めた骨長比デー夕を元に推定した，重 心位置は，鳥が西脚そろっている時の静止画像，また静止 状態から歩行状態へ移り変わる瞬間の画像より推定した。

\section{3. 実步行モデルのデータ評価}

Fig. 3-1 に代表的な 1 羽のエミューによる 1 歩の歩行モ デルと，1歩中の脚長の変化率を示す。点線は単脚, 実線 は両脚支持期を示す。これより，歩行中重心の上下運動が 少なく，また脚長は縮小傾向を示すことが確認できる。こ のように，脚長を大きく変化させることにより，重心高さ がほほ一定に保たれていると考えられる。

\section{4. 線形倒立振子モ一ド}

梶田 ${ }^{4)}$ は，単脚支持期における 2 足歩行ロボットを Fig. 4-1 に示すような重心と支点からなる倒立振子として扱う と, 単脚支持期中重心を進行方向へと進めさせる, 非常に シンプルな運動機構になることを明らかにした。また重心 が直線上,あるいは重心一支点間距離を一定として動くと， そのダイナミックスを線形化でき，その運動は以下に示す 軌道エネルギーと呼ばれる一定值に依存する。

$$
E_{1}=\frac{1}{2} v_{x s}^{2}-\frac{g}{2 z_{5}} x_{5}^{2}, E_{2}=\frac{1}{2} r_{15} \dot{\theta}_{15}^{2}+g \cos \theta_{15}
$$

ここで, $\left\{\mathrm{x}_{5}, \mathrm{v}_{\mathbf{x}}\right\}$ は重心水平位置と水平速度, $\left\{\mathrm{r}_{15}, \theta_{15}, \dot{\theta}{ }_{15}\right\}$ は支点から重心までの距離, 角度, 角速度を示す。このよ うに，重心が直線上を動く倒立振子の運動パターンを二次 元 Linear Inverse Pendulum Model, 略して LIPM ${ }^{5)}$ と呼び, 重 心一支点間が一定の倒立振子運動を IPM と呼ぶ.

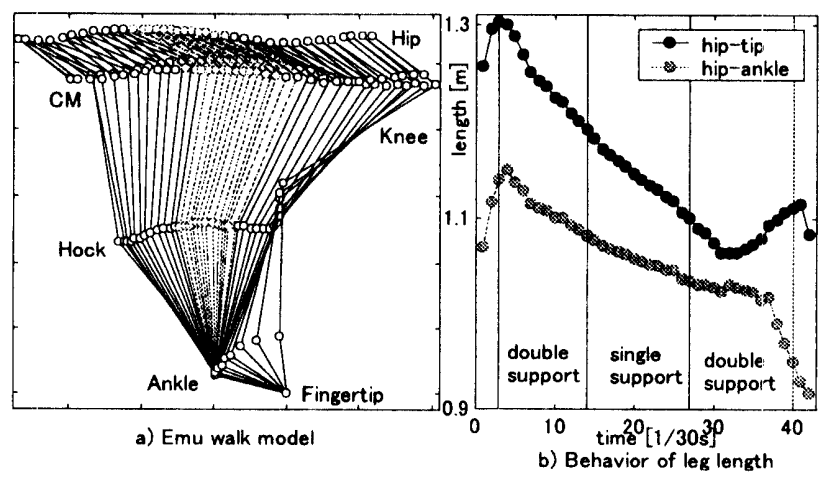

Fig. 3-1 Emu leg model during a single step walk and behavior of supporting leg length.

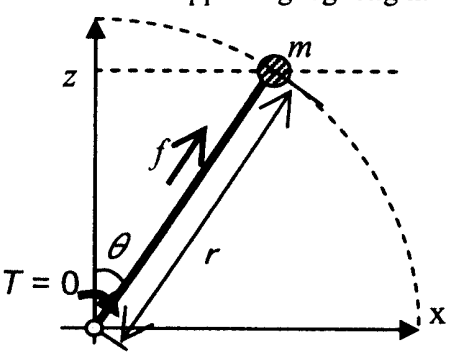

Fig. 4-1 Model of Inverted Pendulum

Fig.4-2にエミューの1歩から得られた軌道エネルギーの 変化を示す. Fig.4-3にこの軌道エネルギーの平均値を用い た LIPM, IPM モデルの運動を示す．点線は実歩行の重心 軌道を示す。これより，単脚支持期におけるエミューの軌 道エネルギーの変化率が小さく, 平均軌道エネルギーを用 いた倒立振子モデルと，単脚支持期における実際のエミュ 一の歩行運動が似ていることがわかる. 


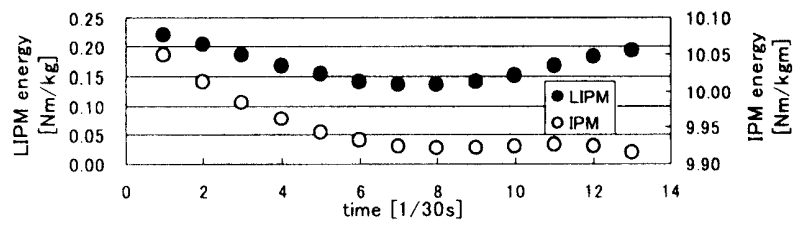

Fig. 4-2 Behavior of Trajectory Energy

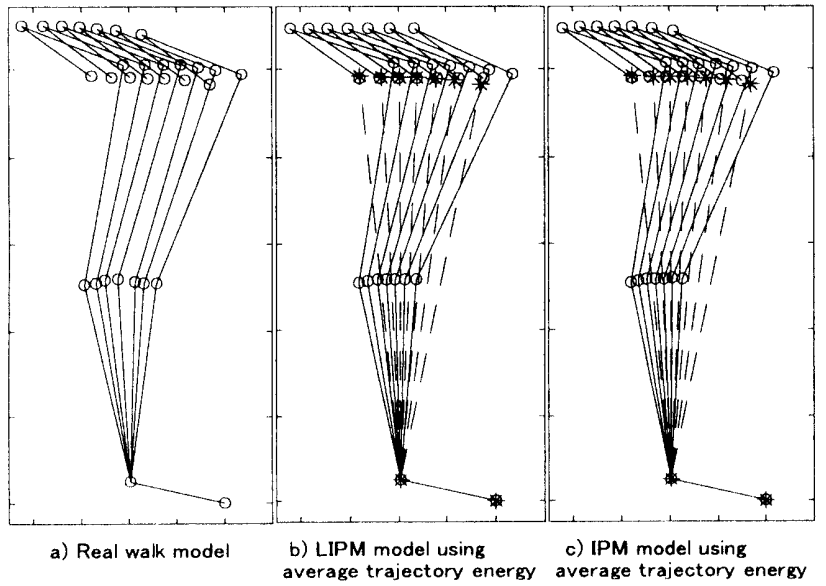

Fig.4-3 Comparison of real walk models with LIPM - IPM

5. 操作力棈円と可探作性棈円

マニピュレータの動きやすさ，操作性を判断するため, 操作力棈円と可操作性楕円を求める手法が挙げられる。操 作力棈円は, マニピュレータの各ジョイントに働くトルク の総計が $\|\tau\| \leqq 1$ を満たすマニピュレータ先端外力 $f$ の 集合, 可操作性棈円は各ジョイントの角速度の総計が $\| \dot{\theta}$ $\| \leqq 1$ を満たす先端速度 vの集合を示し，次のような形で 表される。

$$
f^{T} J(\theta) J^{T}(\theta) f \leq 1 \quad \nu^{T}\left(J^{+}(\theta)\right)^{T} J^{+}(\theta) \nu \leq 1
$$

ここで, $J(\theta)$ はマニピュレータのヤコビ行列, $J^{+}(\theta)$ はヤ コビ行列の擬似逆行列を示す。この操作力棈円の長軸方向 はマニピュレータが外力を発生させやすい方向を示すのに 対し, 可操作性棈円長軸方向は大きな手先速度を出しやす い方向を示す．Fig.5-1 に示すような鳥脚姿勢モデルの Jacobi 行列は,

$$
\begin{gathered}
J_{4}(\theta)=\left[\begin{array}{llll}
J_{1 x} & J_{2 x} & J_{3 x} & J_{4 x} \\
J_{1 z} & J_{2 z} & J_{3 z} & J_{4 z}
\end{array}\right] \\
{\left[J_{i x}, 0, J_{i z}\right]^{T}=s \times\left(L_{5}-L_{i}\right) \quad[i=1, \ldots 4]}
\end{gathered}
$$

と表される。なお， $s=\left[\begin{array}{lll}0 & 1 & 0\end{array}\right]^{\mathrm{T}} ， L_{i}$ は各関節位置を示す，
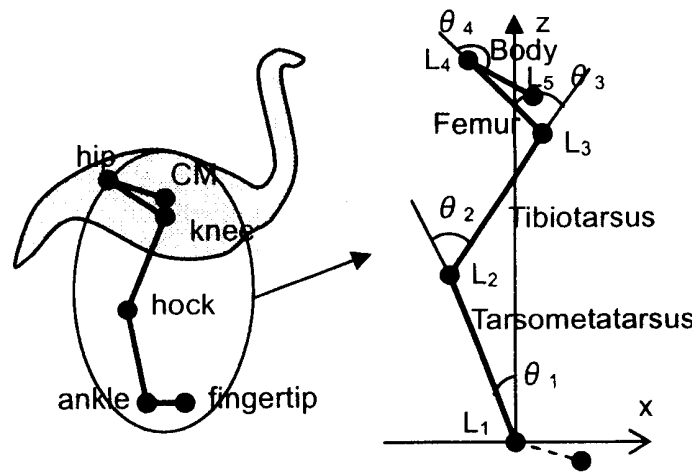

Fig. 5-1 Model of bird leg during single-support phase

Fig. 5-2a)にエミューの実歩行の単脚支持期より得られた 操作力.可操作性棈円主軸を示す.点線は操作力棈円長軸,
そして鎖線は可操作性楕円長軸である。これより，操作力 楕円長軸方向が実歩行の重心に働く外力方向 (休反力方向), あるいは LIPM モデルで歩行を実現させるために必要な外 力方向と類似していることから，鳥の脚姿勢は歩行を実現 させるために必要な外力が発生されやすい脚姿勢と考之ら れる。また，可操作性楕円の長軸方向は，歩行運動におけ る重心の進行方向と近い方向に向いていることが確諗でき る。これより，鳥脚姿勢はスムーズな歩行運動を可能とす るモデルと考えられる。よって，鳥は歩行運動が実現され やすい脚姿勢を持つと考えられる。

Fig． 5-2b)に，エミュ一の股関節を支点，足先を先端と した遊脚姿勢の可操作性棈円を示す。これより，遊脚姿勢 前半の長軸方向は目標着地位置付近に向くのに対し, 後半 は，むしろ短軸方向が着地する方向に近いことがわかる. そこで遊脚期前半は，遊脚をすばやく次の目標地点までに 運び，より早く安定な両脚姿勢を取ることが可能な姿勢と 考えられる。一方, 可操作性棈円長軸方向は動きやすい方 向を示すのに対し，短軸方向は分解能が高く，細かい作業 のしやすい方向といえる。よって遊脚期後半の脚姿勢は， 地面との衝突を抑えやすい姿勢と考えられる。

\section{6. 䊅言}

本文では鳥の歩行と倒立振子理論による歩行を比較し， また歩行における鳥の脚姿勢を評価したところ，以下の結 論を得られた。

・鳥の歩行における重心運動と倒立振子歩行モデルにお ける重心運動に類似性がある。

・鳥の脚姿勢は歩行を実現しやすく，かつ歩行運動をスム 一ズにすることが可能な脚姿勢といえる。

・鳥脚姿勢は着地の衝撃を和らげることが可能といえる。 なお，本文ではエミューの解析結果のみを示したが，ダチ ヨウやレアでも同様の結果が得られた。

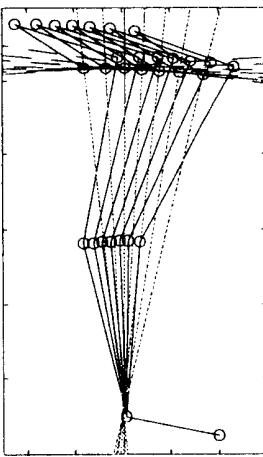

a) Support phase

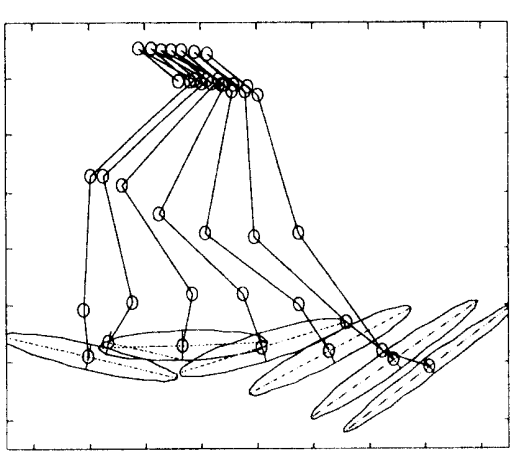

b) Swing phase
Fig.5-2 Ellipsoid axis during support phase and swing phase <参考文献>

1) S.M. Gatesy and K.M. Middleton, Bipedalism, Flight, and the Evolution of Theropod Locomotor Diversity, Journal of Vertebrate Paleontology, Vol.17, No.2, pp.308-329, 1997

2) 森直樹,相田恒一,水戸部和久,那須康雄, 二足ロボット による鳥型及び人間型歩行の実現,日本ロボット学会 誌,Vol.12,No.3,pp.1189-1990, 1994

3）梶田秀司，小林涁，位置エネルギー保存形軌道を規範と する動的 2 足歩行の制御，計测自動制御学会論文集， Vol.23, No.3, pp.281-287, 1987

4）梶田秀司，線形倒立振子モードを規範とする動的 2 足歩 行ロボットの実時間制御, 機械技術研究所報告, 第 171 号, 1996 